JKEP

Vol 6, No 1 (2021)

ISSN: 2338-9095 (Print)

ISSN: 2338-9109 (online)

\title{
Gambaran Perilaku Bullying Verbal Pada Siswa Sekolah Dasar : Literature Review
}

\author{
Indah Pratiwi ${ }^{1}$, Herlina ${ }^{2}$, Gamya Tri Utami ${ }^{3}$ 1,2,3 \\ Fakultas Keperawatan Universitas Riau \\ email:pratiwiindah.ind@gmail.com
}

\author{
Artikel history \\ Dikirim, Sept $10^{\text {th }}, 2020$ \\ Ditinjau, May $25^{\text {th }}, 2021$ \\ Diterima, May $27^{\text {th }}, 2021$
}

\begin{abstract}
Verbal bullying is a common bullying and it can be a trigger for other bullying. Study aims of study to determine the description of verbal bullying behavior in elementary school students. Design of this study used a literature review. There are some tools used to find related articles such as google scholar, PubMed, Plos One, and science direct with the keywords verbal bullying and elementary school students in 2016-2020 period. The research was conducted in 6 different countries such as Australia, Philippines, Brazil, Indonesia, Turkey and Spain. Majority of respondents who took part in the study were female $(51 \%)$, grade $3(31.5 \%)$ with age range of $8-9$ years $(25 \%)$. The results of the description of the prevalence of verbal bullying showed that there were more victims of verbal bullying (95.1\%) with female students as victims (55.9\%). A common form of verbal bullying is insulting or humiliating (30.7\%). The assumption they bully is because of the physical appearance/smell of their friends (49.9\%). The impacts that occurs on students as victims of verbal bullying: decrease in learning achievement (40\%); poor mental health (40\%). Verbal bullying can impacts school-age children to experience decreased learning achievement and poor mental health.
\end{abstract}

Keywords: bullying; elementary school student; verbal bullying

\begin{abstract}
ABSTRAK
Bullying verbal merupakan perilaku yang mudah dilakukan dan bisa menjadi pemicu perilaku bullying lainnya. Tujuan dari penelitian ini untuk mengetahui gambaran perilaku bullying verbal pada siswa sekolah dasar. Desain penelitian menggunakan literature review. Pencarian artikel menggunakan google scholar, PubMed, Plos One, dan science direct dengan kata kunci bullying verbal dan siswa sekolah dasar dalam periode tahun 2016-2020. 8 artikel penelitian yang direview berasal dari 6 negara yaitu Australia, Filipina, Brazil, Indonesia, Turki, dan Spanyol. Hasil dari total responden yang mengikuti penelitian mayoritas berjenis kelamin perempuan $(51 \%)$, kelas $3(31,5 \%)$ dan dengan rentang usia 8-9 tahun (25\%). Hasil gambaran prevalensi bullying verbal didapatkan bahwa lebih banyak jumlah korban bullying verbal $(95,1 \%)$ dengan siswa perempuan sebagai korban $(55,9 \%)$. Bentuk bullying verbal yang umum yaitu menghina atau penghinaan $(30,7 \%)$. Alasan mereka melakukan bullying karena bentuk fisik/bau dari temannya $(49,9 \%)$. Dampak siswa yang mengalami bulllying verbal: penurunan prestasi
\end{abstract}


belajar (40\%); kesehatan mental yang buruk (40\%). Bullying verbal dapat mengakibatkan anak usia sekolah mengalami penurunan prestasi belajar dan buruknya kesehatan mental. Kata kunci: bullying verbal; perilaku; siswa sekolah dasar

\section{PENDAHULUAN}

Masa usia sekolah, anak-anak mulai mengembangkan keterampilan, timbul rasa bersaing, senang berteman dengan sebaya, berperan dalam kegiatan kelompok, menyelesaikan masalah secara mandiri dan mendapatkan rasa penghargaan atas pencapaiannya dalam menyelesaikan tugas yang diberikan. Pengakuan serta penghargaan dari keluarga dan teman sebaya menjadi dorongan dalam memperoleh rasa pencapaian. Hal ini sesuai dengan tugas perkembangan anak usia sekolah yaitu industri versus inferioritas (Hockenberry, Wilson \& Rogers, 2017).

Ketika anak tidak mampu menyelesaikan tugas atau menyelesaikan masalah yang dimiliki serta tidak bisa mencapai tujuan yang diinginkan seperti menjadi juara kelas, membuat anak merasa rendah diri. Perasaan rendah diri mengakibatkan anak menunjukkan perilaku maladaptif seperti menarik diri, mudah tersinggung, tidak percaya diri bahkan melakukan tindakan agresif seperti bullying (Yusuf \& Sugandhi, 2013; Rosdahl \& Kowalski, 2014).
Bullying merupakan perilaku ofensif yang terjadi pada anak usia sekolah yang dilakukan secara sengaja menyebabkan ketidakseimbangan kekuasaan, sehingga membuat orang merasa frustasi, trauma, dan tidak berdaya. Perilaku ini diulang secara langsung atau tidak langsung oleh individu atau kelompok dalam kurun waktu tertentu (Control Disease Center, 2014; Endriani 2018). Faktor penyebab terjadinya bullying pada anak antara lain karena perbedaan kelas, jenis kelamin, iklim sekolah, dendam/iri hati, peranan kelompok/teman sebaya, serta pengetahuan juga berpengaruh dalam munculnya perilaku ini (Usman, 2013; Handalan, 2019).

Data dari UNICEF (2015) 40\% anak mengalami perundungan di sekolah, $32 \%$ mengalami kekerasan fisik, dan sisanya $72 \%$ anak dan remaja menjadi saksi kekerasan. Hasil riset LSM Plan International dan International Center for Research on Women/ICRW (2015) menunjukkan bahwa Asia, kejadian bullying di kalangan siswa sekolah mencapai angka $70 \%$ dan riset tersebut juga menunjukkan bahwa $84 \%$ siswa di Indonesia mengalami kekerasan di 
sekolah. Menurut data KPAI (2019), terdapat beberapa kasus bullying yang terjadi di beberapa daerah di Indonesia. Dari Januari 2019 hingga April 2019, sebagian besar kasus terjadi di jenjang pendidikan dasar/sederajat yaitu sebanyak 25 kasus atau hingga 67\%, SLTP/sederajat sebanyak 5 kasus, 6 kasus pada SLTA/sederajat, dan 1 kasus pada Perguruan Tinggi (PT).

Penelitian yang dilakukan oleh Devita (2019), sebanyak 53\% anak sekolah dan remaja di Pekanbaru pernah mengalami kejadian bullying dengan perlakuan bullying fisik sebanyak 52,8\%, bullying verbal 51,8\%, dan mengalami bullying psikologis/ mental 62,3\%. Penelitian ini tidak sejalan dengan penelitian yang dilakukan oleh Latifah (2012) dari hasil penelitiannya didapatkan bahwa mayoritas tindakan bullying yang sering terjadi pada anak usia sekolah yaitu bullying verbal sebanyak $87 \%$ seperti mengejek nama teman, mengejek nama orang tua, menghina dan menjelekkan bentuk tubuh teman serta melakukan bullying fisik sebanyak $74 \%$ seperti memukul, meludah, menendang temannya. Sejalan dengan penelitian yang dilakukan oleh Anwari (2018) tindakan bullying verbal sering terjadi dikalangan siswa yakni sebanyak $98 \%$ dan bullying fisik sebanyak 50\%.

Bullying verbal merupakan bullying yang disampaikan secara verbal dapat berbentuk perkataan yang mencela, menyoraki, penghinaan, julukan nama, menebar gosip/fitnah, kritikan yang menjatuhkan, ajakan dan ungkapan yang mengarah ke pelecehan seksual, dan sebagainya (Yayasan Semai Jiwa Amini, 2008). Efek dari perilaku bullying dapat menyebabkan perkembangan anak secara psikologis, emosional maupun sosial, hal ini bisa menjadi masalah di masa depan dan menyakiti anak-anak lain (Sucipto, 2016; Sufriani \& Sari, 2017).

Tujuan literature review ini untuk mengetahui dan mengevaluasi gambaran perilaku bullying verbal pada siswa sekolah dasar. Hasil penelitian ini diharapkan dapat digunakan sebagai sumber yang dapat meningkatkan wawasan dan informasi tenaga kesehatan, tenaga pendidik, keluarga dan peneliti lain perihal gambaran perilaku bullying verbal pada siswa sekolah dasar.

\section{METODE PENELITIAN}

Penelitian ini menggunakan metode literature review untuk mengumpulkan, 
mengidentifikasi, mengevaluasi, dan menginterpretasi artikel yang berkaitan dengan gambaran perilaku bullying verbal siswa sekolah dasar. Data yang digunakan dalam penelitian ini berasal dari hasil penelitian yang telah dilakukan dan dipublikasikan di jurnal online nasional maupun internasional. Peneliti menggunakan Google Cendekia, Science Direct, Plos One dan PubMed untuk mencari jurnal yang relavan. Pencarian artikel memakai keyword atau kata kunci yaitu "bullying verbal" dan "siswa sekolah dasar" untuk bahasa Indonesia, "verbal bullying", "elementary school student", atau "primary school student" untuk bahasa Inggris. Artikel-artikel yang didapat selama periode pencarian dipilih sesuai kriteria inklusi.

Proses pengambilan sumber data dilakukan dengan menyaring artikel penelitian yang ditemukan berdasarkan kata kunci, lalu dilakukan screening dan dipilih berdasarkan kriteria yang telah ditetapkan penulis, yaitu: Tahun sumber artikel yang diambil mulai dari tahun 2016 sampai dengan 2020 sesuai dengan keyword penulisan keterkaitan hasil penulisan dan pembahasan; Pencarian artikel dilakukan dengan menggunakan situs online database seperti Google Scholar, Pubmed, Plos One, dan Science Direct; Memasukkan kata kunci sesuai topik literature review kemudian dilanjutkan dengan melakukan penelusuran berdasarkan advance search; Melakukan pencarian artikel yang full text; Melakukan penilaian terhadap artikel dari abstrak sesuai dengan tujuan literature review ini.

Kriteria inklusi dalam penelitian ini, yaitu: Artikel yang berkaitan dengan perilaku bullying verbal pada siswa sekolah dasar; Artikel berbahasa Indonesia dan Inggris; Artikel dalam bentuk original dan full text; Artikel dapat diperoleh tanpa dibayar; Metode penelitian yang digunakan bersifat deskriptif, korelasi, cross sectional, longitudinal, dan studi kohort.

Proses telaah artikel dalam literature review ini dilakukan sesuai dengan Skema 1 
Skema 1. Tahap sistematik literature review

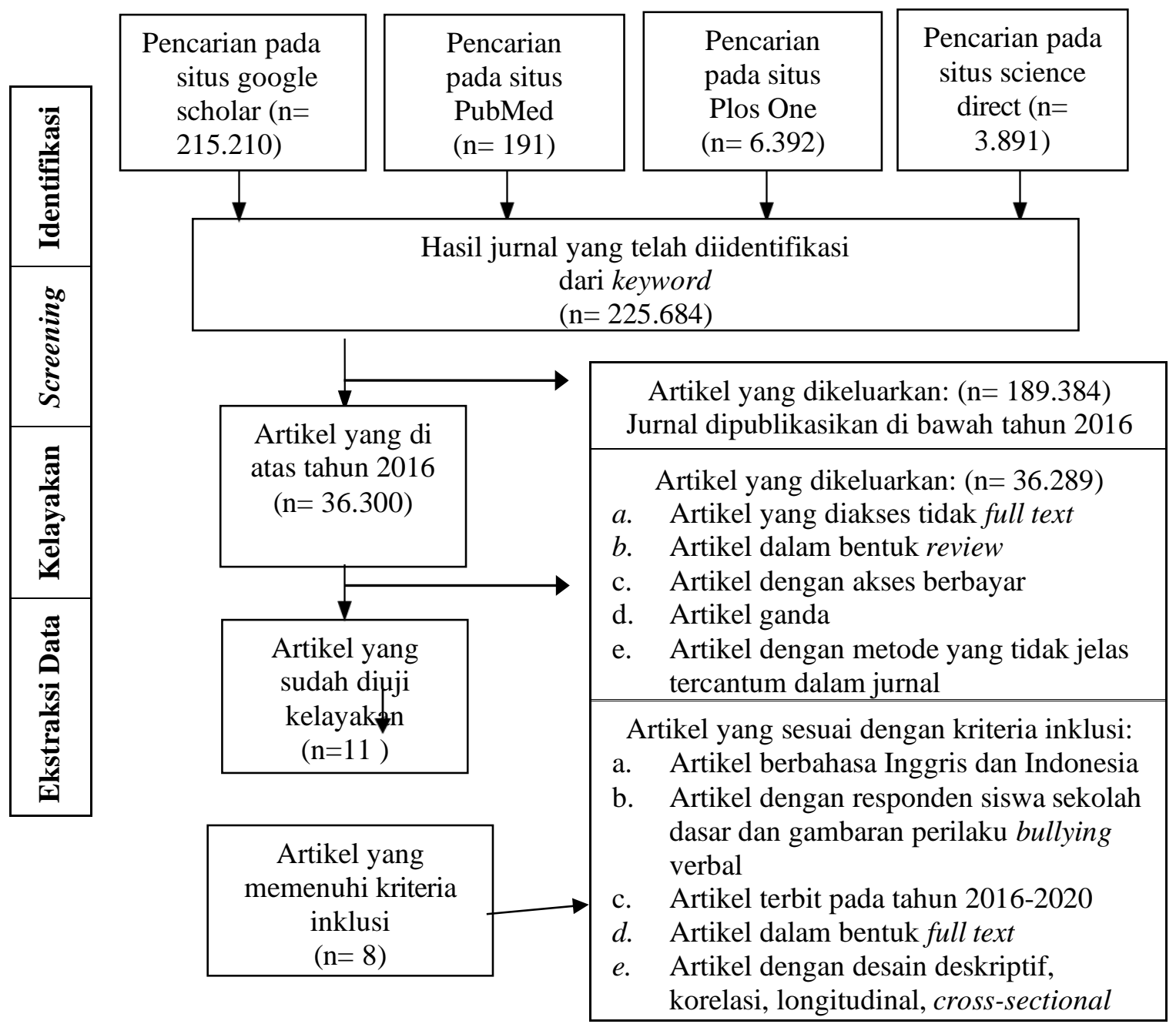


HASIL DAN PEMBAHASAN

Analisis terhadap 8 artikel penelitian yang layak dianalisis ini dituangkan ke dalam Tabel 1.

Tabel 1. Daftar artikel yang direview

\begin{tabular}{|c|c|c|c|c|}
\hline No & $\begin{array}{l}\text { Judul } \\
\text { Penelitian }\end{array}$ & $\begin{array}{c}\text { Tujuan } \\
\text { Penelitian }\end{array}$ & $\begin{array}{c}\text { Metode } \\
\text { Penelitian }\end{array}$ & Hasil / Temuan \\
\hline 1 & $\begin{array}{l}\text { When Kids } \\
\text { Hurt Other } \\
\text { Kids: Bullying } \\
\text { in Philippine } \\
\text { Schools } \\
\text { (Sanapo, } \\
\text { M.S., 2017) }\end{array}$ & $\begin{array}{l}\text { Untuk } \\
\text { mengetahui } \\
\text { prevalensi } \\
\text { jenis-jenis } \\
\text { bullying dari } \\
\text { Korban dan } \\
\text { pelaku } \\
\text { bullying pada } \\
\text { siswa kelas } 6 \\
\text { di Filipina }\end{array}$ & $\begin{array}{l}\text { Desain: Deskriptif } \\
\text { survei } \\
\text { Tempat: Western } \\
\text { Visayas, Filipina } \\
\text { Instrumen: } \\
\text { Kuesioner Olweus } \\
\text { yang dimodifikasi } \\
\text { menggunakan } \\
\text { bahasa Filipina } \\
\text { Sampel } \\
\text { Penelitian: } \\
340 \text { siswa kelas } 6 \\
\text { dari } 5 \text { sekolah } \\
\text { berbeda di } \\
\text { Western Visayas, } \\
\text { Filipina dengan } \\
\text { metode cluster } \\
\text { sampling }\end{array}$ & $\begin{array}{l}\text { Dari keempat jenis tipe bullying } \\
\text { didapatkan hasil bahwa bullying } \\
\text { verbal yang paling banyak } \\
\text { dilakukan oleh pelaku bullying } \\
\text { yaitu sebanyak } 60,5 \% \text { (n=49) } \\
\text { dan dari hasil penelitian } \\
\text { didapatkan verbal bullying juga } \\
\text { merupakan jenis yang paling } \\
\text { banyak dialami oleh korban } \\
\text { bullying yaitu sebanyak } 61,5 \% \\
\text { (n=85). Prevalensi yang paling } \\
\text { banyak melakukan bullying } \\
\text { verbal adalah siswa laki- laki } \\
\text { (63,5\%) dari total } 184 \\
\text { responden laki-laki } \\
\text { dibandingkan siswa perempuan } \\
\text { (55,2\%) dari total } 156 \\
\text { responden perempuan dan } \\
\text { prevalensi korban yang } \\
\text { mengalami verbal bullying } \\
\text { setara antara laki-laki (61,90\% } \\
\text { dari total responden laki-laki) } \\
\text { dan perempuan (61,11\% dari } \\
\text { total responden perempuan). }\end{array}$ \\
\hline
\end{tabular}




\begin{tabular}{|c|c|c|c|c|}
\hline No & $\begin{array}{l}\text { Judul } \\
\text { Penelitian }\end{array}$ & $\begin{array}{c}\text { Tujuan } \\
\text { Penelitian }\end{array}$ & $\begin{array}{c}\text { Metode } \\
\text { Penelitian }\end{array}$ & Hasil / Temuan \\
\hline 2. & $\begin{array}{l}\text { Prevalence of } \\
\text { Bullying and } \\
\text { Cyberbullying } \\
\text { in the Last } \\
\text { Stage of } \\
\text { Primary } \\
\text { Education in } \\
\text { the Basque } \\
\text { Country } \\
\text { (Machimbarre } \\
\text { na } \\
\text {, J.M., \& } \\
\text { Garaigordobil, } \\
\text { M., 2018) }\end{array}$ & $\begin{array}{l}\text { Untuk } \\
\text { mengetahui } \\
\text { prevalensi } \\
\text { bullying dan } \\
\text { cyberbullying } \\
\text { pada siswa } \\
\text { kelas } 5 \text { dan } 6\end{array}$ & $\begin{array}{l}\text { Desain: Deskriptif } \\
\text { comparative } \\
\text { metode cross- } \\
\text { sectional design } \\
\text { Tempat: Basque } \\
\text { Country, Spanyol } \\
\text { Instrumen: } \\
\text { Kuesioner } \\
\text { "Cyberbullyin g: } \\
\text { Screening } \\
\text { Of Peer- } \\
\text { Harassment" } \\
\text { Sampel } \\
\text { Penelitian: } 1.993 \\
\text { siswa } \\
\text { kelas } 5 \text { dan } 6 \\
\text { (usia 9-13 } \\
\text { tahun) dari } 25 \\
\text { sekolah dasar di } \\
\text { Basque Country, } \\
\text { Spanyol dengan } \\
\text { metode random } \\
\text { sampling }\end{array}$ & $\begin{array}{l}\text { Hasil penelitian menunjukan } \\
\text { bahwa bullying verbal menjadi } \\
\text { bentuk bullying yang paling } \\
\text { sering terjadi baik dari pihak } \\
\text { korban maupun pelaku. } \\
\text { Penelitian mengelompokkan } \\
\text { data berdasarkan pelaku dan } \\
\text { korban dari perilaku bullying. } \\
\text { Prevalensi korban yang } \\
\text { mengalami bullying verbal } \\
\text { sebanyak } 36,6 \% \quad(\mathrm{n}=730) \\
\text { sedangkan prevalensi pelaku } \\
\text { yang melakukan bullying verbal } \\
\text { sebanyak } 23,9 \%(\mathrm{n}=476) .\end{array}$ \\
\hline 3. & $\begin{array}{l}\text { Bullying, } \\
\text { Mental Health } \\
\text { and Friendship } \\
\text { in Australian } \\
\text { Primary School } \\
\text { Children } \\
\text { (Bayer, J.K., } \\
\text { Mundy, L., } \\
\text { Stokes, I., } \\
\text { Heraps, S., } \\
\text { Allen, N., \& } \\
\text { Patton, G., } \\
\text { 2018) }\end{array}$ & $\begin{array}{l}\text { Untuk } \\
\text { mengetahui } \\
\text { prevalensi } \\
\text { bullying yang } \\
\text { sering terja } \\
\text { di dan } \\
\text { hubungannya } \\
\text { dengan } \\
\text { kesehatan } \\
\text { mental; untuk } \\
\text { mengetahui } \\
\text { apakah } \\
\text { sahabat peran } \\
\text { menjadi bisa }\end{array}$ & $\begin{array}{l}\text { Desain: Studi } \\
\text { longitudinal/ } \\
\text { Childhood to } \\
\text { Adolescence } \\
\text { Transition Study } \\
\text { (CATS) } \\
\text { Tempat: } \\
\text { Melbourne, } \\
\text { Australia } \\
\text { Instrumen: } \\
\text { Kuesioner } \\
\text { Gatehouse } \\
\text { Bullying Scale } \\
\text { (GBS) } \\
\text { Sampel }\end{array}$ & $\begin{array}{l}\text { Hasil penelitian dari } 1221 \\
\text { responden didapatkan } 277 \\
\text { anak }(22,7 \%) \text { mengalami } \\
\text { bullying verbal dan } 169 \\
\text { anak }(13,8 \%) \\
\text { bullying fisik. Selebihnya } 90 \\
\text { anak (7,4\%) mengalami } \\
\text { keduanya yaitu gabungan dari } \\
\text { bullying verbal dan fisik. } \\
\text { Apabila dikategorikan } \\
\text { berdasarkan jenis kelamin, dari } \\
277 \text { responden yang mengalami } \\
\text { bullying verbal didapatkan } \\
\text { sebanyak } 142 \text { anak (51,3\%) } \\
\text { merupakan siswa perempuan } \\
\text { sedangkan pada siswa laki-laki } \\
\text { didapatkan hasil 135 anak } \\
\text { (48,7\%). Hasil penelitian ini }\end{array}$ \\
\hline
\end{tabular}




\begin{tabular}{|c|c|c|c|c|}
\hline No & $\begin{array}{l}\text { Judul } \\
\text { Penelitian }\end{array}$ & $\begin{array}{c}\text { Tujuan } \\
\text { Penelitian }\end{array}$ & $\begin{array}{c}\text { Metode } \\
\text { Penelitian }\end{array}$ & Hasil / Temuan \\
\hline & & $\begin{array}{l}\text { pelindung dari } \\
\text { kesehatan } \\
\text { mental korban } \\
\text { bullying }\end{array}$ & $\begin{array}{l}\text { Penelitian: } 1221 \\
\text { anak usia } \\
8-9 \text { tahun } \\
\text { kelas } 3 \text { dari } 43 \\
\text { sekolah dasar di } \\
\text { Melbourne, } \\
\text { Australia dengan } \\
\text { metode } \\
\text { stratified random } \\
\text { sampling }\end{array}$ & $\begin{array}{l}\text { dapat disimpulkan bahwa } \\
\text { bullying verbal banyak terjadi } \\
\text { pada siswa perempuan } \\
\text { meskipun tidak ada perbedaan } \\
\text { yang signifikan. }\end{array}$ \\
\hline 4. & $\begin{array}{l}\text { Peer } \\
\text { Victimisation } \\
\text { and Academic } \\
\text { Performance in } \\
\text { Primary School } \\
\text { Children } \\
\text { (Mundy, L.K., } \\
\text { Canterford, L., } \\
\text { Kosola, S., } \\
\text { Degenhardt, } \\
\text { L., Allen, } \\
\text { N.B., \& } \\
\text { Patton, G.C., } \\
\text { 2017) }\end{array}$ & $\begin{array}{l}\text { Untuk melihat } \\
\text { hubungan } \\
\text { antara bullying } \\
\text { kelompok } \\
\text { (peer } \\
\text { victimisation) } \\
\text { dengan } \\
\text { prestasi } \\
\text { akademik pada } \\
\text { siswa sekolah } \\
\text { dasar }\end{array}$ & $\begin{array}{l}\text { Desain: Studi } \\
\text { Kohort/Childh } \\
\text { ood to } \\
\text { Adolescence } \\
\text { Transition Study } \\
\text { (CATS) } \\
\text { Tempat: } \\
\text { Melbourne, } \\
\text { Australia } \\
\text { Instrumen: } \\
\text { Kuesioner } \\
\text { Gatehouse bullying } \\
\text { scale dan } \\
\text { NAPLAN } \\
\text { Sampel } \\
\text { Penelitian: } 965 \\
\quad \text { anak } \\
\text { dengan usia } 8 \text { - } \\
9 \text { tahun kelas } 3 \\
\text { dari sekolah } \\
\text { dari } \quad 43 \\
\text { sekolah dasar di } \\
\text { Melbourne, } \\
\text { Australia dengan } \\
\text { metode stratified } \\
\text { random } \\
\text { sampling }\end{array}$ & $\begin{array}{l}\text { Penelitian menunjukkan } 154 \\
\text { anak (16\%) mengalami } \\
\text { bullying verbal dan menjadikan } \\
\text { jenis bullying ini sebagai } \\
\text { tindakan yang paling banyak } \\
\text { terjadi. Hasil penelitian } \\
\text { menunjukkan dari responden } \\
\text { laki-laki didapatkan sebanyak } \\
65 \text { anak (42,2\%) yang } \\
\text { mengalami bullying verbal } \\
\text { sedangkan pada responden } \\
\text { perempuan didapatkan } \\
\text { sebanyak } 89 \text { anak (57,8\%) yang } \\
\text { mengalami bullying verbal. } \\
\text { Pada siswa perempuan, } \\
\text { bullying verbal berhubungan } \\
\text { dengan buruknya prestasi } \\
\text { akademik dalam menulis dan } \\
\text { tata 58ahasa/tanda baca. Pada } \\
\text { siswa laki-laki, bullying verbal } \\
\text { tidak ada hubungannya dengan } \\
\text { buruknya prestasi akademik. }\end{array}$ \\
\hline
\end{tabular}




\begin{tabular}{|c|c|c|c|c|}
\hline No & $\begin{array}{l}\text { Judul } \\
\text { Penelitian }\end{array}$ & $\begin{array}{c}\text { Tujuan } \\
\text { Penelitian }\end{array}$ & $\begin{array}{l}\text { Metode } \\
\text { Penelitian }\end{array}$ & Masin / 10 \\
\hline 5. & $\begin{array}{l}\text { Bullying in } \\
\text { the } \\
\text { Countryside: } \\
\text { Prevalence, } \\
\text { Factors, and } \\
\text { Coping } \\
\text { Mechanism } \\
\text { (Wong, J.P., } \\
\& \\
\text { Wong, A.M., } \\
\text { 2017) }\end{array}$ & $\begin{array}{l}\text { Untuk } \\
\text { mengetahui } \\
\text { jenis bullying } \\
\text { yang } \\
\quad \text { sering } \\
\text { dilakukan oleh } \\
\text { siswa sekolah } \\
\text { dasar; } \\
\quad \text { untuk } \\
\text { mengetahui } \\
\text { aspek apa saja } \\
\text { yang } \\
\text { berhubungan } \\
\text { dengan } \\
\text { tindakan } \\
\text { bullying di } \\
\text { sekolah umum } \\
\text { negeri di } \\
\text { Distrik } \\
\text { Romblon, } \\
\text { Filipina }\end{array}$ & $\begin{array}{l}\text { Tempat: } \\
\text { Distrik } \\
\text { Romblon, } \\
\text { Filipina } \\
\text { Instrumen: } \\
\text { Kuesioner dan } \\
\text { wawancara } \\
\text { terstruktur } \\
\text { Sampel } \\
\text { Penelitian: } \\
\text { 187 siswa } \\
\text { kelas } 6 \text { dari } 2 \\
\text { sekolah di } \\
\text { Distrik Romblon, } \\
\text { Filipina dengan } \\
\text { metode total } \\
\text { sampling atau } \\
\text { sampling } \\
\text { jenuh }\end{array}$ & $\begin{array}{l}\text { Hasil penelitian ditemukan } \\
\text { bahwa bullying verbal menjadi } \\
\text { jenis bullying yang paling } \\
\text { sering terjadi pada siswa. Hasil } \\
\text { penelitin menunjukkan bahwa } \\
158 \text { dari } 187 \text { anak ( } 84,50 \%) \\
\text { mengalami bullying verbal } \\
\text { dalam bentuk } \\
\text { dihina/penghinaan, } 138 \text { dari } \\
187 \text { anak ( } 73,80 \%) \text { mendapat } \\
\text { perlakuan berupa makian/kata- } \\
\text { kata kasar, } 117 \text { dari } 187 \text { anak } \\
\text { (65,57\%) diejek oleh } \\
\text { temannya, } 113 \text { dari } 187 \text { anak } \\
\text { (60,42\%) dibully dengan } \\
\text { diolok-olok namanya, dan } 53 \\
\text { dari } 138 \text { anak (28,24\%) } \\
\text { mendapat perlakuan dalam } \\
\text { bentuk kecaman/celaan. }\end{array}$ \\
\hline 6. & $\begin{array}{l}\text { The } \\
\text { Relationship } \\
\text { between Types } \\
\text { of Bullying } \\
\text { experien ced by } \\
\text { Primary School } \\
\text { Students and } \\
\text { Their Anxiety, } \\
\text { State- Trait, } \\
\text { Self- Esteem } \\
\text { and Certain } \\
\text { Socio- } \\
\text { Demographic } \\
\text { Characteristic } \\
\text { (Demirbag, } \\
\text { B.C., Cicek, } \\
\text { Z., } \\
\text { Yigitbas, C., } \\
\text { Ozkan, C.G., }\end{array}$ & $\begin{array}{l}\text { Untuk } \\
\text { mengetahui } \\
\text { hubungan } \\
\text { antara bentuk } \\
\text { bullying } \\
\text { terhadap } \\
\text { kecemasan } \\
\text { (ansietas), } \\
\text { sifat, harga } \\
\text { diri (self- } \\
\text { esteem), \& } \\
\text { karakteristik } \\
\text { sosio- } \\
\text { demografis } \\
\text { pada siswa } \\
\text { sekolah dasar } \\
\text { yang } \\
\text { mengalami } \\
\text { bullying }\end{array}$ & $\begin{array}{l}\text { Sampel } \\
\text { Penelitian: } \\
595 \text { siswa sekolah } \\
\text { dasar kelas 4-6 } \\
\text { (9-13 tahun) di } \\
\text { Turki dengan } \\
\text { metode simple }\end{array}$ & $\begin{array}{l}\text { Hasil penelitian menunjukkan } \\
\text { bahwa dari total } 590 \text { siswa yang } \\
\text { mengalami bullying verbal, } \\
\text { mereka melaporkan paling } \\
\text { banyak mengalami tindakan } \\
\text { bullying dalam bentuk candaan } \\
\text { (14,1\%), diikuti celaan atau } \\
\text { ungkapan kebencian } \\
\text { sebanyak 12\%, bentuk } \\
\text { menghina/hinaan sebanyak } \\
10,5 \% \text {, selebihnya dalam } \\
\text { bentuk mengejek, mengolok- } \\
\text { olok nama, dan } \\
\text { menggunjing. Data dari } \\
\text { penelitian juga memperlihatkan } \\
\text { bahwa bullying verbal menjadi } \\
\text { perilaku bullying yang lebih } \\
\text { sering terjadi pada siswa. }\end{array}$ \\
\hline
\end{tabular}




\begin{tabular}{|c|c|c|c|c|}
\hline No & $\begin{array}{l}\text { Judul } \\
\text { Penelitian }\end{array}$ & $\begin{array}{c}\text { Tujuan } \\
\text { Penelitian }\end{array}$ & $\begin{array}{c}\text { Metode } \\
\text { Penelitian }\end{array}$ & Hasil / Temuan \\
\hline & $\begin{array}{l}\& \text { Dincer, } \\
\text { A., 2017) }\end{array}$ & & random sampling & \\
\hline 7. & $\begin{array}{l}\text { Korelasi } \\
\text { Tindaka n } \\
\text { Bullying } \\
\text { dengan Hasil } \\
\text { Belajar Siswa } \\
\text { Kelas Tinggi } \\
\text { Sekolah Dasar } \\
\text { Negeri } 27 \text { Pauh } \\
\text { Desa Tahun } \\
\text { Pelajaran } \\
\text { 2018/2019 } \\
\text { (Wedyawaty, } \\
\text { N., \& Makin, } \\
\text { T.D.I.R., } \\
\text { 2019) }\end{array}$ & $\begin{array}{l}\text { Untuk } \\
\text { mengetahui } \\
\text { hubungan } \\
\text { antara } \\
\text { tindakan } \\
\text { bullying } \\
\text { dengan } \\
\text { belajar hasil } \\
\text { a kelas tinggi } \\
\text { di SDN } 27 \\
\text { Pauh Desa } \\
\text { tahun } \\
\text { pelajaran } \\
\text { 2018/2019 }\end{array}$ & $\begin{array}{l}\text { Sampel Penelitian: } \\
45 \\
\text { siswa kelas 4- } \\
6 \text { di SDN } \\
27 \text { Pauh } \\
\text { Desa } \\
\text { dengan } \\
\text { metode } \\
\text { sampling } \\
\text { jenuh }\end{array}$ & $\begin{array}{l}\text { Hasil dari penelitian } \\
\text { menunjukkan bullying } \\
\text { verbal menjadi tipe bullying } \\
\text { yang paling sering dialami oleh } \\
\text { siswa dengan persentase } \\
\text { bullying verbal sebanyak } \\
41,26 \% \text { di kelas IV, } 42,12 \% \\
\text { di kelas V, dan } 37,84 \% \text { di } \\
\text { kelas VI. Perilaku bullying } \\
\text { mempunyai hubungan } \\
\text { signifikan dengan hasil } \\
\text { belajar pada siswa kelas V } \\
\text { ( } \mathrm{p}=0,001<\alpha=0,05 \text { ) dan VI } \\
\text { (p=0,033< } \alpha=0,05) \text { sedangkan } \\
\text { pada kelas IV tidak ada } \\
\text { hubungan perilaku bullying } \\
\text { dengan hasil belajar } \\
\text { (p=0,462> } \alpha=0,05 \text { ). }\end{array}$ \\
\hline 8. & $\begin{array}{l}\text { Untreated } \\
\text { Dental Caries } \\
\text { is Associated } \\
\text { with reports of } \\
\text { verbal bullying } \\
\text { in children 8- } \\
10 \text { years old } \\
\text { (Barasoul, } \\
\text { J.C.,et al.2017) }\end{array}$ & $\begin{array}{l}\text { Untuk } \\
\text { mengetahui } \\
\text { hubungan } \\
\text { antara bullying } \\
\text { verbal pada } \\
\text { anak yang } \\
\text { mengalami } \\
\text { karies gigi } \\
\text { yang tidak } \\
\text { diobati } \\
\text { (masalah pada } \\
\text { gigi) }\end{array}$ & $\begin{array}{l}\text { Desain : } \\
\text { Deskriptif } \\
\text { korelasional } \\
\text { Tempat : } \\
\text { Santa Carina, } \\
\text { Brazil } \\
\text { Instrumen : } \\
\text { Kuisioner } \\
\text { Child } \\
\text { Perception 8- } \\
\text { 10 (CPQ 8-10) } \\
\text { dan data klinis } \\
\text { yang } \\
\text { dikumpulkan } \\
\text { oleh } 4 \\
\text { pemeriksa }\end{array}$ & $\begin{array}{l}\text { Didapatkan hasil } 429(27 \%) \\
\text { anak melaporkan telah menjadi } \\
\text { korban bullying verbal terkait } \\
\text { dengan kondisi karies gigi yang } \\
\text { tidak diobati dibanding mereka } \\
\text { yang kesehatan giginya terjaga. } \\
\text { Hasil analisis deskriptif juga } \\
\text { menunjukkan bahwa bullying } \\
\text { verbal ini lebih sering terjadi } \\
\text { pada anak perempuan }(28,8 \%) \\
\text { dengan usia prevalensi tertinggi } \\
\text { yaitu usia } 8 \text { tahun }(29,1 \%) \text {. }\end{array}$ \\
\hline
\end{tabular}




\begin{tabular}{llll}
\hline No Judul & \multicolumn{1}{c}{ Tujuan } \\
Penelitian & \multicolumn{1}{c}{$\begin{array}{c}\text { Metode } \\
\text { Penelitian }\end{array}$} & Hasil / Temuan \\
\hline & menggunakan \\
& indeks DMFT \\
dan PUFA & untuk karies \\
& gigi \\
& Sampel \\
& Penelitian \\
& 1.589 anak \\
& usia 8-10 \\
& tahun dari \\
& sekolah dasar \\
& umum di Kota \\
& Florianopolis, \\
& Brazil dengan \\
metode \\
stratified \\
cluster \\
sampling \\
\end{tabular}

Literature review yang dilakukan pada 8 artikel penelitian didapatkan hasil bahwa setiap artikel menggunakan metode penelitian, teknik sampling, dan instrumen penelitian yang berbeda-beda. Mayoritas artikel penelitian menggunakan metode penelitian deskriptif survei dan deskriptif korelasional. Deskriptif survei merupakan penelitian yang bersifat observasional dengan tujuan untuk melihat gambaran suatu keadaan secara objektif dalam satu waktu, sedangkan deskriptif korelasional melihat gambaran serta hubungan antara variabel yang dinilai secara simultan dalam satu kali waktu (Notoatmodjo, 2018).

Teknik sampling mayoritas menggunakan teknik total sampling dan stratified random sampling. 2 artikel penelitian menggunakan total sampling yaitu penelitian Wong \& Wong (2017) dan Wedyawati \& Makin (2019). Total sampling adalah pengambilan sampel yang menggunakan semua nggota populasi sebagai sampel penelitian (Sugiyono, 2018). 2 artikel penelitian lainnya menggunakan stratified random sampling yaitu penelitian Mundy et al (2017) dan Bayer et al (2018). Stratified random sampling merupakan metode 
pengambilan sampel yang menitikberatkan pada tingkat keseluruhan sampel (Sugiyono, 2018).

Instrumen penelitian yang digunakan pada 8 artikel penelitian yang di review juga berbeda-beda, kecuali 2 artikel oleh Mundy et al. (2017) dan Bayer et al. (2018) yang menggunakan kuesioner gatehouse bullying scale. Kuesioner ini reliabel untuk mengukur perilaku bullying di sekolah. Penelitian yang dilakukan oleh Mundy et al (2017) ingin melihat hubungan pengalaman bullying yang dialami seseorang dengan prestasi akademik yang buruk sehingga Mundy et al (2017) juga menggunakan National Assessment

Programe-Literacy

and Numeracy/NAPLAN dalam mengumpulkan data kemampuan akademik siswa. NAPLAN menilai prestasi akademik pada lima domain, yaitu membaca, menulis, berhitung, mengeja, dan tata bahasa/tanda baca. Kuesioner Olweus yang telah diadaptasi kedalam bahasa Filipina digunakan oleh Sanapo (2017) dalam menilai perilaku bullying. Kuesioner terdiri dari beberapa bagian pertanyaan mengenai perilaku agresif dari pelaku, jenis perilaku bullying yang sering dilakukan, siapa yang selalu menjadi korban, dan mengidentifikasi perbedaan kekuatan antara pelaku dan korban.

Machimbarrena \& Garaigordobil (2018) menggunakan kuesioner cyberbullying: screening of peer-harassment. Kuesioner yang digunakan sudah baku yang mampu mengevaluasi bullying langsung dan cyberbullying. Wong \& Wong (2017) menggunakan kuesioner dan wawancara terstruktur dalam pengumpulan data yang disusun berdasarkan pernyataan masalah dan studi terkait. Bagian pertama dari kuesioner tersebut membahas pengalaman bullying yang dialami oleh siswa baik secara verbal atau fisik. Bagian kedua membahas faktor- faktor yang berhubungan dengan perilaku bullying. Bagian ketiga tentang mekanisme koping dari siswa yang mengalami bullying. Bagian keempat mengenai program yang dilakukan oleh sekolah untuk mengatasi bullying.

Demirbag et al (2017) menggunakan kuesioner violence and brute force yang terdiri dari pertanyaan mengenai jenis perilaku bullying yang dilakukan seperti bullying fisik, verbal, emosional, atau psikososial, tempat terjadinya bullying, kepada siapa meminta bantuan setelah 
mengalami bullying, serta respon terhadap kejadian bullying. Barasuol et al (2017) menggunakan kuesioner Child Perception 8-10 (CPQ 8-10) digunakan untuk mengukur kualitas hidup anak terkait kesehatan rongga mulut pada usia 8-10 tahun. Wedyawati \& Makin (2019) menggunakan raport siswa sebagai instrumen untuk melihat hasil belajar siswa sedangkan Barasuol et al (2017) menggunakan data klinis yang dikumpulkan oleh 4 pemeriksa terkalibrasi menggunakan indeks DMFT dan PUFA untuk melihat hubungan bullying verbal terhadap anak yang mengalami karies gigi yang tidak ditangani.

Literature review yang dilakukan pada 8 artikel penelitian, hanya 7 artikel yang menjelaskan distribusi responden berdasarkan jenis kelamin. Dari total 6.935 responden, sebanyak 3.545 berjenis kelamin perempuan dan 3.203 lainnya adalah laki-laki. Hasil ini menunjukkan bahwa anak perempuan lebih mungkin mengalami bullying verbal karena jenis kelamin dapat secara langsungatau tidak langsung mempengaruhi sifat, kepribadian, dan emosi. Dalam masyarakat, anak perempuan perlu bersikap feminim, sehingga mereka lebih cenderung ramah dan lemah lembut, karenanya terbentuk kepribadian perempuan menjadi pemalu. Lingkungan masyarakat juga menuntut anak laki-laki untuk tidak lemah dan lebih aktif, yang nantinya akan membuat anak laki-laki terlihat lebih berani dan percaya diri (Friedman, 2010).

Literature review yang dilakukan pada 8 artikel penelitian, diketahui bahwa ada 5 artikel menjelaskan jumlah responden berdasarkan distribusi usia dan tingkatan kelas dengan hasil mayoritas responden berada di kelas 3 (31,5\%) dengan rentang usia 8-9 (25\%). Anak yang berada di kelas rendah dan usia muda lebih sering mengalami bullying karena banyak memiliki harga diri rendah (Demirbag et al, 2017). Hal ini sesuai dengan perkembangan psikososial anak usia sekolah yang mulai mengembangkan potensi, memperoleh kompetensi serta mengembangkan keterampilan mereka, sehingga ketika memperoleh kegagalan mereka lebih sering merasa rendah diri dan menjadi tidak percaya diri (Potter \& Perry, 2010).

Hasil dari literature review didapatkan bahwa jumlah korban bullying verbal $(95,1 \%)$ lebih banyak dibandingkan 
pelaku. Hasil review juga menunjukkan korban bullying verbal banyak dialami oleh siswa perempuan $(55,9 \%)$. Hal ini dikarenakan siswa laki-laki lebih cenderung merespon tindakan bullying dengan melawan sebagai bentuk pembelaan (Demirbag et al, 2017).

Hasil literature review dari 3 artikel didapatkan informasi bahwa bullying verbal umum dilakukan dalam bentuk menghina atau penghinaan (30,7\%). Mereka menjadikan nama atau membuat julukan, bahkan menjadikan fisik atau kekurangan dari korban sebagai bahan untuk menghina dan mengolok-olok korbannya. Bentuk lainnya yang juga dilakukan adalah mengejek, menggoda, dan memaki korbannya (Demirbag et al., 2017; Sanapo, 2017; Wong \& Wong, 2017). Berbagai macam alasan mereka ungkapkan sebagai alasan melakukan bullying verbal.

Hasil literature review menunjukkan bahwa alasan paling umum mereka melakukan bullying karena tidak menyukai bentuk fisik/bau dari temannya (49,9\%). Perilaku bullying yang dilakukan bisa berawal dari kondisi atau sesuatu yang berbeda secara fisik atau sifat (kepribadian) dari kebanyakan anak pada umumnya baik secara positif maupun negatif, seperti kulit gelap, mata sipit, berkacamata tebal, rambut keriting, terlalu tinggi atau terlalu besar, bahkan terlalu rajin atau terlalu pintar bisa menjadi alasan pencetus terjadinya bullying (Hertinjung \& Karyani, 2015).

Hasil literature review dari 3 artikel menjelaskan dampak dari bullying verbal, siswa yang mengalami bulllying verbal mayoritas mengalami penurunan prestasi belajar (40\%) dan kesehatan mental yang buruk (40\%). Hasil penelitian Mundy et al (2017) dan Wedyawati dan Makin (2019) menunjukkan bahwa siswa yang mengalami bullying verbal mengalami rendahnya skor NAPLAN dan adanya hubungan tindakan bullying dengan hasil belajar. Penanganan perilaku bullying penting untuk dilakukan karena anak yang mengalami bullying memiliki resiko lebih tinggi mengalami penurunan prestasi akademik (Kowalski \& Limber, 2013). Dampak lainnya yaitu buruknya kesehatan mental dari anak-anak yang mengalami bullying dalam menunjukkan emosi dan perilaku sehingga menyebabkan mereka sulit untuk memiliki teman. Hal ini sesuai dengan penelitian yang dilakukan oleh 
Albuhairan, F, Abou Abbas, O, El Sayed, D, Badri, M, Alshahri, S, \& De Vries, N. (2017) bahwa tindakan bullying menyebabkan seseorang mengalami masalah kesehatan mental dan prestasi akademik yang buruk.

Korban bullying juga dijauhi oleh teman yang bukan bagian dari pelaku bullying. Hal ini dilakukan karena mereka takut menjadi sasaran bullying berikutnya. Tidak memiliki teman tentunya berpotensi memperburuk dampak dari bullying dan memiliki sekelompok teman lebih berpotensi melindungi kesehatan mental mereka (Wong \& Wong, 2017; Bayer et al., 2018). Hal ini tentu tidak akan memutus rantai siklus bullying dan menjadi alasan dari munculnya perilaku bullying lainnya.

\section{SIMPULAN}

Bullying verbal menjadi tindakan bullying yang banyak dilakukan siswa sekolah dasar. Siswa perempuan menjadi korban terbanyak (55,9\%). Bullying verbal umum dilakukan dalam bentuk menghina atau penghinaan $(30,7 \%)$ dengan alasan bahwa mereka tidak menyukai bentuk fisik/bau dari temannya $(49,9 \%)$. Siswa yang mengalami bulllying verbal mengalami penurunan prestasi belajar dan kesehatan mental yang buruk. Penelitian selanjutnya dapat meneliti lebih lanjut mengenai pemberian intervensi dan program yang tepat guna mencegah dan mengurangi perilaku bullying ini pada siswa sekolah dasar.

\section{UCAPAN TERIMA KASIH}

Terima kasih kepada semua pihak yang telah berperan dalam kelancaran dan kesuksesan untuk penelitian ini.

\section{DAFTAR RUJUKAN}

Albuhairan, F., Abou Abbas, O., El Sayed, D., Badri, M., Alshahri, S., \& De Vries, N. (2017). The relationship of bullying and physical violence to mental health and academic performance: A cross-sectional study among adolescents in Kingdom of Saudi Arabia. International journal of pediatrics and adolescent medicine, 4(2), 61-65. Diakses pada tanggal 17 Juni 2020 di https://doi.org/10.1016/j.ijpam.20 16.12 .005

Anwari, M. (2018). Gambaran perilaku bullying siswa di sekolah dasar negeri Jember Lor 1 Kecamatan Patrang Kabupaten Jember. Diakses pada tanggal 11 Maret 2020 di https://repository.unej.ac.id/handl e/123 456789/84886 
Barasuol, J. C., et al. (2017). Untreated Dental Caries Is Associated With Reports Of Verbal Bullying In Children 8-10 Years Old. Caries Research, 51, 482-488. Diakses pada tanggal 07 Juni 2020 dari https://doi.org/10.1159/00047904 3

Bayer, J. K., Mundy, L., Stokes, I., Hearps, S., Allen, N., \& Patton, G. (2018). Bullying, Mental Health And Friendship In Australia Primary School Children. Child and Adolescent Mental Health, 23(4), 334-340. Diakses pada tanggal 05 Juni 2020 dari https://doi.org/10.1111/camh.1226 1

Control Disease Center : National Center for Injury Prevention and Control. (2014). Bullying suicide. Diakses pada tanggal 11 Maret 2020 dari http://www.cdc.gov/violencepreve ntio n/pdf/bullying-suicidetranslation- finala.pdf

Demirbag, B. C., Cicek, Z., Yigitbas, C., Ozkan, C. G., \& Dincer, A. (2017). The Relationship Between Types Of Bullying Experienced By Primary School Student And Their Anxiety, State- Trait, Self-Esteem, And Certain Socio- Demographic Characteristics. Social and Behavioral Sciences, 237, 398404. Diakses pada tanggal 06 Juni 2020 dari https://doi.org/10.1016/j.sbspro.20 17.02 .077
Devita, Y. (2019). The Effect Of Health Education On Bullying Knowledge Among Primary School Student. Jurnal Proteksi Kesehatan, 8(2), 28-34. Diakses pada tanggal 11 Januari 2020 dari http://jurnal.pkr.ac.id/index.php/J $\mathrm{PK} / \mathrm{a}$ rticle/view/161

Endriani, A., \& Juliani. (2018). Pengaruh Teknik Biblioterapi Terhadap Perilaku Bullying Pada Siswa Kelas VIII Di SMP Negeri 3 Pringgabaya. Jurnal Visionary, 5(1). Diakses pada tanggal 07 Januari $2020 \quad$ dari http://139.59.120.216/index.php/vi sion

ary/article/download/1213/1014

Friedman, M. M., Bowden, V. R., \& Jones, E. G. (2010). Buku Ajar Keperawatan Keluarga: Riset, Teori, \& Praktik (5 ${ }^{\text {th }}$ ed). Jakarta: EGC

Handalan, M. A. (2019). Hubungan Pengetahuan Dan Mekanisme Koping Terhadap Tindakan Bullying Pada Anak Usia Sekolah. Skripsi tidak dipublikasikan

Hertinjung, W. S., \& Karyani, U. (2015). Profil Pelaku dan Korban Bullying Di Sekolah Dasar. PROSIDING SEMINAR NASIONAL \& INTERNASIONAL. Diakses pada tanggal 17 Agustus 2020 dari http://103.97.100.145/index.php/psn1 2 012010/article/view/1535 
Hockenberry, M., Rodgers, C., \& Wilson, D. (2017). Wong's Essential of Pediatric Nursing. Ed. 7. Elsevier Health Sciences

ICRW. (2015). Are School Safe And Gender Equal Spaces?. Diakses pada tanggal 07 Januari 2020 dari https://www.icrw.org/publications /are- schools-safe-and-genderequal-spaces/

Kowalski, R. M., \& Limber, S. P. (2013). Psychological, Physical, and Academic Correlates of Cyberbullying And Traditional Bullying. Journal of adolescent health, 53(1), S13-S20. Diakses pada tanggal 17 Agustus 2020 di https://doi.org/10.1016/j.jadohealt h.20 12.09.018

KPAI. (2019). KPAI: 67 Persen Kekerasan Bidang Pendidikan Terjadi Di Jenjang SD. Diakses pada tanggal 10 September 2019 dari

https://www.kpai.go.id/berita/kpai -67- persen-kekerasan-bidangpendidikan- terjadi-di-jenjang-sd

Latifah, F. (2012). Hubungan Karakteristik Anak Usia Sekolah dengan Kejadian Bullying Di Sekolah Dasar X Di Bogor. Skripsi. Jakarta: Fakultas Ilmu Keperawatan Universitas Indonesia. Diakses pada tanggal 25 Januari 2020 dari http://lib.ui.ac.id/file?file=digital/ 20313561S43718Hubungan\%20k arakteristik.pdf
Machimbarrena, J. M., \& Garaigordobil, M. (2018). Prevalence of bullying and cyberbullying in the last stage of primary education in the Basque Country. The Spanish Journal of Psychology, 21, 48. Diakses pada tanggal 05 Juni 2020 dari https://doi.org/10.1017/sjp.2018.4 1

Notoatmodjo, S. (2018). Metodologi Penelitian Kesehatan. Jakarta: Rineka Cipta

Mundy, L. K., Canterford, L., Kosola, S., Degenhardt, L., Allen, N. B., \& Patton, G. C. (2017). Peer Victimisation and Academic Performance In Primary School Children. Academic Pediatrics, 17(8), 830-836. Diakses pada tanggal 06 Juni 2020 dari https://doi.org/10.1016/j.acap.201 7.06. 012

Rosdahl, C. B., \& Kowalski, M. T. (2014). Buku ajar keperawatan dasar Ed 10 Volume 1. Jakarta: EGC

Sanapo, M. S. (2017). When Kids Hurt Other Kids: Bullying In Philippine Schools. Psychology, 8, 24692484. Diakses pada tanggal 5 Juni 2020 dari https://doi.org/10.4236/psych.201 7.814156

Sucipto, S. (2016). Bullying dan Upaya Meminimalisasikannya. PSIKOPEDAGOGIA Jurnal bimbingan dan konseling, 1(1) 
Sufriani, S., \& Sari, E. P. (2017). Faktor yang Mempengaruhi Bullying Pada Anak Usia Sekolah Di Sekolah Dasar Kecamatan Syiah Kuala Banda Aceh. Idea Nursing Journal, 8(3). Diakses pada tanggal 11 Maret 2020 dari http://www.jurnal.unsyiah.ac.id/I NJ/ar ticle/view/9678/7951

Sugiyono. (2018). Metode Penelitian Kuantitatif, Kualitatif, Dan $R \& D$. Bandung: Alfabeta

UNICEF. (2015). Annual Results Report 2015. Diakses pada tanggal 07 Januari $2020 \quad$ dari https://www.unicef.org/publicpartner $\mathrm{s}$

hips/files/2015ARR_ChildProtection. pdf

Usman, I. (2013). Perilaku Bullying Ditinjau Dari Peran Kelompok Teman Sebaya Dan Iklim Sekolah Pada Siswa SMA Di Kota Gorontalo. Gorontalo: Universitas Gorontalo. Diakses pada tanggal 07 Januari 2020 dari https://s3.amazonaws.com/acade mia.edu.documents/51278834/jur nal_1.pdf
Wedyawati, N., \& Makin, T. D. I. R. (2019). Korelasi Tindakan Bullying dengan Hasil Belajar Siswa Kelas Tinggi Sekolah Dasar Negeri 27 Pauh Desa Tahun Pelajaran 2018/2019. VOX EDUKASI: Jurnal Ilmiah Ilmu Pendidikan, 10(1), 29-44. Diakses pada tanggal 20 Juni 2020 dari https://doi.org/10.31932/ve.v10i1.35 7

Yayasan Semai Jiwa Amini (SEJIWA). (2008). Bullying: Mengatasi Kekerasan di Sekolah dan Di Lingkungan Sekitar Anak. Jakarta: Penerbit PT. Grasindo

Yusuf, S., \& Sugandhi, N. M. (2013). Perkembangan Peserta Didik. Depok: PT Raja Grafindo Persad 